\title{
Extreme case formulations in \\ Spanish pre-electoral debates and English panel interviews
}

ISABEL IÑIGO-MORA

UNIVERSITY OF SEVILLE

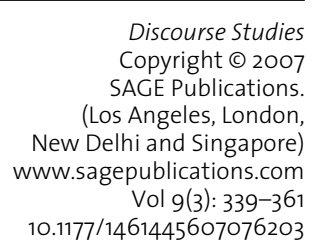

ABSTRACT This article is concerned with Extreme Case Formulations (ECFs) (Edwards, 2000; Pomerantz, 1986) in multiple-party TV programmes in two different languages: Spanish and English. I examine the role of ECFs in Spanish pre-electoral debates and in English panel interviews. English data is 77 minutes and 58 seconds long and comprises nine different panel interviews of political, socio-political and social issues and Spanish data is 78 minutes long and includes four political pre-electoral debates. The results will disclose that the number of ECFs found in the Spanish and in the English corpora differs considerably (48 versus 81 ). And in relation to the type of recording, the data will reveal that a) interviewers and interviewees deployed many more ECFs in political recordings ( 2.8 percent) than in socio-political (1.2 percent) or social recordings (1.3 percent); and b) politicians used more ECFs ( 4.8 percent) than any other type of interviewees ( 1.5 percent).

KEY WORDS: discursive psychology, extreme case formulation, hyperbole, panel interviews, persuasion, pre-electoral debate

\section{Introduction}

This article is concerned with Extreme Case Formulations (ECFs) (Edwards, 2000; Pomerantz, 1986) in multiple-party TV programmes in two different languages: Spanish and English. We are going to examine the role of ECFs in Spanish pre-electoral debates and in English panel interviews. We examine data from 155 minutes and 58 seconds of TV programmes in both Spanish and English. English data is 77 minutes and 58 seconds long and comprises nine different panel interviews of political, socio-political and social issues and Spanish data is 78 minutes long and includes four political pre-electoral debates.

Any full account of ECFs must have an interactive dimension and it is for this reason that we include information about ECFs studies carried out in the 
field of what is known as Discursive Psychology (Edwards and Potter, 1992). As Edwards (2004) explains:

Discursive psychology studies the relationship between mind and world, as psychology generally does, but as a discourse topic, that is, as a participants' concern, a matter of talk's business, talk's categories, talk's rhetoric, and talk's current interactional concerns. [AQ]

First of all we are going to offer some frameworks for the study of ECFs. These include information about 1) Discursive Psychology and ECFs, 2) ECFs and hyperbole, and 3) ECFs and persuasion. Then, we will carry out an analysis which includes a full account of the lexico-grammatical repertoire and discourse processes found in the data. And finally, we will discuss the results.

\section{Frameworks for the study of ECFs}

\section{DISCURSIVE PSYCHOLOGY AND ECFS}

Discursive Psychology (DP) is a new approach which analyses discourse as a situated, action-oriented and constructed activity (Edwards and Potter, 1992). It is situated because '... talk and texts are embedded in sequences of interaction, and in various kinds of mundane and institutional activity' and because '... DP considers discourse pervasively rhetorical' (Edwards and Potter, 2001: 13). One important idea is that talk is oriented to but not determined by its sequential position and setting. The analyst should not adopt a stance based on predictions; discourse is an ongoing activity constructing and making relevant the participants' emotional feelings and attitude. Attitudes, in turn, are examined as evaluative practices done in discourse. And it is rhetorical because when people offer an evaluation they are normally reacting against somebody else's evaluation. So, discourse is not so much shaped by somebody's thoughts as by the development of a rhetorical argumentation (Billig, 1991; Edwards and Potter, 2001; Pomerantz, 1986). In this way, DP regards discourse as both constructed and constructive because it studies the way discourse itself is constructed and the way discourse constructs versions of the world. Edwards and Potter (2001: 14-15) explain that 'Words, metaphors, idioms, rhetorical devices, descriptions, accounts, stories, and so on, are drawn on, and built, in the course of interaction and in the performance of particular actions' and '... [DP] studies how versions of inner life, of local circumstances, of history and broader social groups and structures are produced to do particular things in interaction.'

One important strand of investigation in DP is related to the way an individual's evaluations and descriptions mirror his/her own stance. One example is the use of what Pomerantz calls (1986) 'extreme case formulations' (ECFs). Edwards (2000: 347-8) explains that ECFs are '.. descriptions or assessments that deploy extreme expressions such as every, all, none, best, least, as good as it gets, always, perfectly, brand new, and absolutely'. Pomerantz (1986: 227) summarizes the three main uses of ECFs in the following way: 
1. to assert the strongest case in anticipation of non-sympathetic hearings,

2. to propose the cause of a phenomenon,

3. to speak for the rightness (wrongness) of a practice.

It is really interesting to note that these ECFs are very weak in the sense that it is extremely easy to refute them. If somebody mentions just one counterexample, the validity of the ECFs is in jeopardy. For this reason, it is very common to find a softer version ('a softener') right after an ECF has been challenged (Pomerantz, 1986). The order is: ECF-challenge-softener. Here is an example (Edwards, 2000: 355):

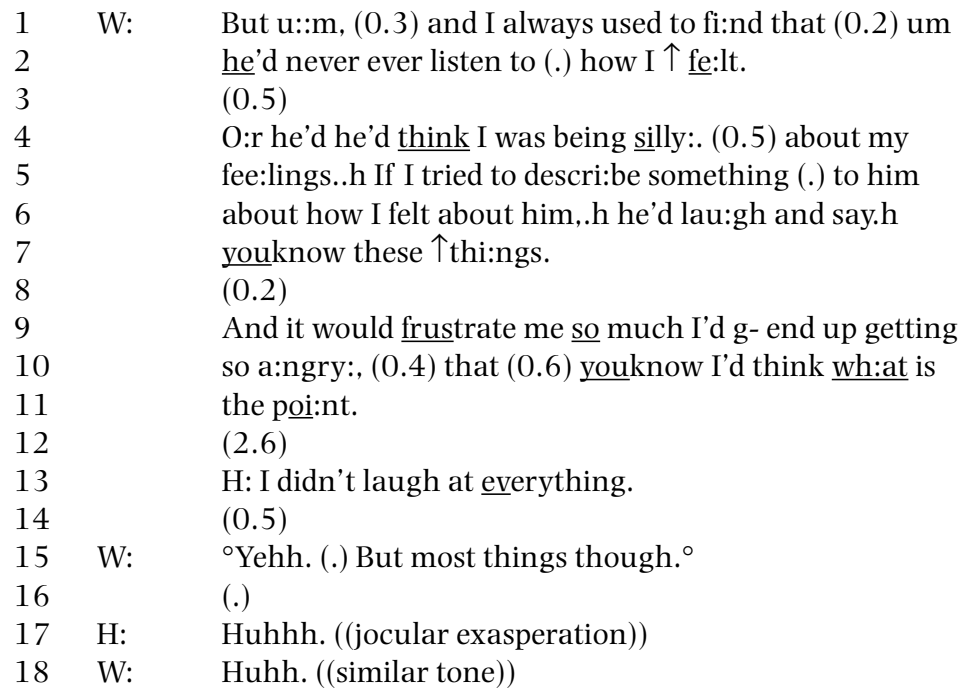

In this conversation the wife (W) uses two ECFs (lines 1 and 2): 'always' and 'never' and both are challenged with 'everything' (line 13). Finally, the wife is 'forced' to utter a softener version and says 'most things' (line 15).

Despite the 'weakness' of these ECFs it is interesting to note that Edwards (2000) has discovered that the use of these ECFs is very popular and widespread. The reason is that most of the times people accept them and orient to their non-literal interpretations.

\section{ECFS AND HYPERBOLE}

According to Norrick (2004), although ECFs are a sub-category of hyperbole, they are essentially different from non-extreme hyperboles in a number of ways:

1. ECF matches the typical apodictic ${ }^{1}$ tone of proverbs, while hyperbolic imagery fits the colourful character of proverbial phrases and idioms.

2. While both ECF and non-extreme hyperbole are heard as defeasible and non-literal, and can occur adjacent to one another in everyday talk, ECFs generally embed extreme expressions in otherwise literal-seeming talk, while hyperbole often takes the form of imagery and is surrounded by obviously non-literal talk. 
3. ECF and hyperbole are comprehended differently: ECFs violate the truthfulness maxim, while non-extreme hyperboles violate only the quantity maxim or are heard as approximations to the speaker's beliefs.

If we compare hyperbolic utterances such as 'the line's a mile long' with ECFs such as 'this line has no end at all' or 'this line will never end' we can conclude that whereas the first violates the quantity maxim but not the quality maxim, the second does violate the quality maxim (Gibbs, 1994; Norrick, 2004). According to Grice (1975: 46), under the category of quality falls a supermaxim ('Try to make your contribution one that is true') and two more specific maxims:

1. Do not say what you believe to be false.

2. Do not say that for which you lack adequate evidence.

Gibbs (1994) explains that the difference lies in the speaker's intentions. When somebody utters a non-extreme hyperbole such as 'The line's a mile long' the listener knows that it is not the speaker's intention to say something which is false but rather to say something which varies in length (i.e. there is an approximation), that is, in quantity. On the other hand, when somebody says 'The line has no end at all', s/he is saying something which is false. In fact, ECFs and hyperboles receive different responses in following talk. Norrick (2004: 1737) explains that:

Any participant in a conversation, including the one who produces an ECF, may contradict it with impunity in immediately following talk. The speaker who produces a non-extreme hyperbole may scale it down, if other participants question its validity.

\section{HYPERBOLE AND PERSUASION}

According to Roiz (1993) persuasive strategies are oriented to: 1) diminish the listeners' psychological resistance; 2) verify the correct transmission of the message; and 3) attract listeners' attention. So, it is necessary to know well the person we want to persuade in order to use these procedures adequately. Roiz (1993) also suggests six persuasive rules:

1. exploitation of the feelings;

2. simplification;

3. exaggeration and distortion of information;

4. repetition of topics and ideas in an orchestral way;

5. exploitation of the psychological contagion;

6. support of pre-existing attitudes.

Roiz (1993) states that exaggeration of the information is a widely recognized strategy among persuaders. This author (Roiz, 1993: 59) offers a table ${ }^{2}$ which summarizes the main types of procedures used (Table 1).

Similarly, when Cockcroft and Cockcroft (1992) describe the schematic language used when persuading, they include 'Amplification and Diminution' (auxesis and meiosis ${ }^{3}$ ) and explain that Amplification and diminution can be 
TABLE 1. Procedures

\begin{tabular}{|c|c|c|}
\hline Principle or rule & Main procedures & Type of procedure \\
\hline \multirow[t]{3}{*}{$\begin{array}{l}\text { Exaggeration and distortion } \\
\text { of information }\end{array}$} & $\begin{array}{l}\text { The conviction is produced when } \\
\text { appealing to the power of the } \\
\text { referential facts which have been } \\
\text { previously distorted }\end{array}$ & Psychological \\
\hline & $\begin{array}{l}\text { - Biased treatment of the reality } \\
\text { - The description of the facts is } \\
\text { accompanied by categorical } \\
\text { opinions which distort them }\end{array}$ & Argumentative \\
\hline & $\begin{array}{l}\text { - The original menaing is } \\
\text { distorted and substituted by } \\
\text { a favourable menaing to the } \\
\text { speaker's persuasive capacity } \\
\text { - All or some of the details of the } \\
\text { event are exaggerated in a way } \\
\text { that favours the success of the } \\
\text { persuasion } \\
\text { - Judgements about the facts are } \\
\text { distorted and convergent and } \\
\text { contrasted codes are sometimes } \\
\text { used (serious, humoristic, } \\
\text { burlesque, cynical) }\end{array}$ & $\begin{array}{l}\text { Linguistic and } \\
\text { semiological }\end{array}$ \\
\hline
\end{tabular}

used both to develop an argument in detail, and to shorten it; to enhance the importance of the subject, and to denigrate it. Either can produce powerful persuasive effects, often involving the use of trope' (Cockcroft and Cockcroft, 1992: 132). And the first device they examine is the hyperbole.

\section{Corpus analysis}

The analysis of this corpus is divided into two big sections: 'Spanish preelectoral debates' and 'English panel interviews'. Each section is subdivided into three parts: 'Lexico-grammatical repertoire', 'Discourse processes' and 'Sequential organization in conversation'. The reason why I have decided to analyse my corpus using these three criteria is because the semantic, the syntactic and the conversational levels go hand-in-hand in real-life language. For example, if a speaker A needs something which a hearer B has, s/he may say either: 'Could I borrow this?' or 'I need this'. Semantically speaking, both utterances have the same illocutionary force: a request, but the level of indirectness and the syntax are different. Language is a matter of choice and behind each choice there are conversational and contextual explanations which justify each option. For this reason, in order to offer a detailed analysis of any corpus taken from real life it is necessary to take into account all these three levels. 


\section{SPANISH PRE-ELECTORAL DEBATES}

The Spanish corpus selected for analysis is made up of four recordings of four pre-electoral debates broadcasted by Canal Sur Televisión. In this type of debate each interviewee has a pre-established and limited time to talk and turn-toturn discussion among interviewees is not allowed. The interviewer is simply a moderator who allocates turns among interviewees and acts as arbitrator when this turn allocation system is in jeopardy.

The length of these recordings is 78 minutes (19 minutes and 30 seconds each). There are four interviewees and one interviewer in all of them. The interviewees are politicians who represent different political parties in the Andalusian Regional Elections (14 March 2004). The details of each of these recordings is:

- First recording:

Date: 5 February 2004

Interviewees: Mr Caballos (PSOE); Mr Sanz (PP); Mr Calvo (PA); Mr Romero (IU)

- Second recording:

Date: 19 February 2004

Interviewees: Ms Álvarez (PSOE); Mr Fuentes (PP); Mr Benavides (PA); Ms Caballero (IU)

- Third recording:

Date: 26 February 2004

Interviewees: Mr Soler (PSOE); Mr Ramos (PP); Mr Del Olmo (PA); Mr Vaquero (IU)

- Fourth recording:

Date: 4 March 2004

Interviewees: Mr Chaves (PSOE); Ms Martínez (PP); Mr Ortega (PA); Mr Valderas (IU)

\section{Lexico-grammatical repertoire}

The total number of ECFs found in this corpus is 48. After having analysed all of them I arrived at the conclusion that they could be classified in five categories. The criteria used for this classification is twofold: syntactic and semantic. In this way, we find the following categories: totality, exclusiveness or zero, extreme adjectives or adverbs and superlatives, numbers, intensifiers.

Totality These EFCs express the total number or the amount of something or they describe something which happens all the time. They are 'todos/o/as' ('all') and 'siempre' ('always'). The first one was the most numerous of all ECFs. We found 15 examples of 'todos/o/as' ('all') and only one of 'siempre' ('always'). Here is one example of each:

First recording: 5 February 2004:

You not should be unaware that in all the surveys of

Mr Caballos: USTED no debe desconocer (0.5) que en todas las ENCUESTAS de 
opinion the Andalusians are satisfied and opinión (0.8) los andaluces (0.3) están <SATISEECHOS $>(0.5)$ y

(they) approve clearly the services that (they) receive in education aprueban (0.4) con creces los servicios que reciben en educación (0.5)

in public health in care health the pensions the en sanidad (0.4) en atención sanitaria (0.4) las pensiones (0.3) las roads the culture the tourism all is in the carreteras $(0.3)$ la cultura $(0.2)$ el turismo $(0.2)$ todo está en las surveys encuestas.

Fourth recording: 4 March 2004.

because besides in these nearly fourteen years of presidency (you) should

Ms Martínez: porque además en estos casi.hh catorce años de presidente se tenían have got used to be more polite que haber acostumbrado a ser más respetuoso $=$

Mr Cháves: always so (I) have been $=\underline{\text { SIEMPRE lo he [sido] }}$ yes not

Ms Martínez:

getting nervous [ ya ] no ponerse nervioso $=$ always so (I) have been and above all with you Ms. Martínez

Mr Cháves: =siempre lo he sido [y sobre todo con usted señora Martíne] look I'm you going to tell then

Ms Martínez:

let me speak. [mire yo le voy a decir ] pues

déjeme hablar.

It is interesting to observe that the second extract is one of those special cases of turn-to-turn-talk with interruptions and overlaps. It is equally notable that the overlap is produced when the Mr Cháves says 'siempre' ('always'). Ms Martínez ignores this 'siempre', which contradicts her previous utterance, and continues. Instead of rectifying, Mr Cháves insists and repeats the ECF 'siempre'. Edwards (2000) explains that when an ECF is challenged it is normally followed by a softener. In this example, although 'siempre' is not explicitly challenged there is a direct attack and the ECF is not recognized as a reasonable defence. In cases like this the opposite happens: the ECF is repeated. Indeed, for Ms Martínez to pursue and challenge Mr Cháves's ECF would have spoiled the main trajectory of her talk, which was to open up some space for her to say, without interruption, whatever she wanted to say next.

Exclusiveness and zero In this category we include examples of absolute negation or instances of ECFs which describe qualities limited to a particular person or group. We found the following formulations: 'no hay quien' (there is nobody who), 'ni una sóla' ('not even one'), 'nunca' ('never'), 'ningún/a' ('no one'), 'nada' ('nothing'), 'solo' ('only'), 'único' ('single'), 'exclusivamente' ('exclusively'). Only 
one example of each was found except for 'nunca' and 'ningún/a' (two examples of each) and 'solo/a' (three examples):

Fourth recording: 4 March 2004.

Andalusia is growing in employment since ago ten years

Mr Cháves: Andalucía está creciendo en empleo desde hace diez años without a break ten years since the year 1994 ininterrumpidamente (0.3) diez años (0.3) desde el año 1994

ruling Felipe González ten years and you gobernando (0.3) Felipe González diez años (0.7) y USTEDES

never it have acknowledged Ms. Martínez never it have NUNCA lo han reconocido (1) señora Martínez NUNCA lo han acknowledged reconocido.

Fourth recording: 4 March 2004.

one throws the ball to the other but the fact (I) think that is that if Mr Valderas: uno le tira la pelota al otro (0.7) pero la realidad yo creo que es que si::

not are in a position to see Andalucía from a (0.4) no ( ) estáis en una posición de ver Andalucía < desde::> una perspective exclusively virtual or of art paper perspectiva exclusivamente virtual o de papel cuché.

Extreme adjectives or adverbs and superlatives This category is made up of adjectives which express the greatest degree of a particular quality and adverbs which denote the highest frequency of an event. In this group we have found: one 'permanentemente' ('permanently'), one 'vital' ('vital'), one 'imposible' ('impossible'), one 'importantísima' ('most important'), one 'mejor' ('best'), three 'peor' ('worst'), three 'más' ('most').

\section{First recording: 5 February 2004:}

that Teófila Martínez is the leader political worst

Mr Caballos: que Teófila Martínez (0.7) es (0.3) la LÍDER política peor

valued of the four who are running

valorada (0.2) de los cuatro que se presentan.

Third recording: 26 February 2004:

We are going to have the same situation present of frustration

Mr Del Olmo: vamos a tener (0.3) la MISMA situación actual de FRUSTRACIÓN

In numerous strata of the society which see that it's a

en numerosas capas de la sociedad (0.3) que ven que es una

necessity imposible to meet with wages in

$<$ NECESIDAD $>(0.5)$ imposible de cubrir con unos sueldos (0.3) en which if they get a mortgage (they) are not left even 100

los que si entran en una <hipoteca> $(0.5)$ no les queda ni siquiera 100

euros to finish the month

euros para terminar el mes. 
Numbers Only one number was found 'mil veces' ('a thousand times'). Even though 'a thousand times' is not mathematically (and so semantically) an ECF, it is used as such in actual talk. It is very interesting to note that this ECF is preceded and followed by two ECF: 'todos' ('all') and 'siempre' ('always').

\section{First recording: 5 February 2004:}

insists the Mr. Spokesman of the PP his speech of all these

Mr Caballos: insiste:: el <señor portavoz del:: PP hh su discurso de todos estos

years in the Parliament what do you mean (you) have not said it in Parliament años en el Parlamento cómo que no lo ha dicho en el Parlamento? (you) it have said a thousand times you always say the same that Andalusia is (0.6) lo ha dicho mil veces SIEMPRE dice lo mismo que Andalucía es a disaster un desastre.

Intensifiers There is one example of intensifier: 'absolutamente nada' ('absolutely nothing'). In this case an extreme adverb precedes an ECF:

\section{First recording: 5 February 2004:}

Yes let's see if me me respect some time because (you) don't don't respect

Mr Sanz:

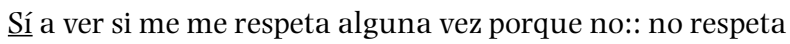
absolutely nothing and because I know that you hurt these things because absolutamente nada y es que yo se que le duelen estas cosas porque that (it) is allowed to say these things in Andalusia when they que se puedan decir estas cosas (0.3) en Andalucía cuando ellos permanently do that in the parliament (it) is not allowed permanentemente (0.4) hacen que en el parlamento no se puedan to say decir.

This intensified ECF is also followed by another ECF 'permanentemente' ('permanently').

\section{Discourse processes}

ECFs may not be used in isolation but followed by a challenge or by another ECF. We have already seen some examples where multiple ECFs are used by the same speaker and in the same turn. What it is really interesting is the repetition of the same ECF in the same turn. We found five examples of repetition in our corpus: 1) 'siempre lo he sido - siempre lo he sido' ('I've always been - I've always been'); 2) 'ningún - ninguna' ('none - none'); 3) 'X tiene la culpa de todo - Y tiene la culpa de todo - Z tiene la culpa de todo' ('X gets the blame for everything' 'Y gets the blame for everything' - 'Z gets the blame for everything'); 4) 'toda España - toda España' ('all Spain - all Spain'); 5) ‘ustedes nunca lo han reconocido - ustedes nunca lo han reconocido' ('you have never acknowledged it - you have never acknowledged it'). Three of them (the second, the fourth and the fifth) 
were produced by the same speaker and in the same turn. One possible reason for these repetitions is that they provide:

... a relief from the demands of face-to-face interaction: the speaker is provided with an opportunity to plan what he or she will say next while the listener's processing demands are diminished with the redundancy that accompanies repetition. (Ehrlich, 1994: 87)

In contrast to this, the first and the third examples were uttered in conflicting turn takings. The first one is produced when Mr Cháves is interrupted by Ms Martínez and that is the reason why he repeats the ECFs. The third is produced in the following context:

Second recording: 19 February 2004:

Ms Álvarez: I knew that at the end (I) would get the blame for

Mr Fuentes: señora Álvarez (0.6) yo sabía que al final iba a tener la culpa de everything

todo $=$

you not

Ms Álvarez: $\quad=$ usted no=

because lately the party popular gets the blame for everything and

Mr Fuentes: =porque últimamente el partido popular (0.4) tiene la culpa de todo $\mathrm{y}$ (we) go on getting the blame seguimos teniendo la culpa $=$

Ms Álvarez: $\quad=[\mathrm{hh}]$

it (I) say because (we) are going to get the blame for everything

Mr Fuentes: [ lo ] digo porque es que vamos a tener la culpa de todo= no

Ms Álvarez: $\quad=$ no::=

the chart on the table

Mr Fuentes: $\quad=$ el gráfico de la mesa (...)

The ECF is challenged by two negations 'usted no' ('you not') and 'no' but instead of being followed by a softener (Edwards, 2000), the ECF is repeated. This defiant behaviour is repeated in a much more explicit example of ECF + challenge + softener:

Second recording: 19 February 2004:

And I'm not going to say that (I) don't permit you it because I permit you

Mr Fuentes: $\quad$ y $\underline{\text { no }}$ le voy a decir que no se lo permito (0.5) porque yo a usted se lo

everything

permito $\underline{\text { todo }}=$

not everything

Ms Álvarez: =no todo no=

after seven years sharing with you the Parliament

Mr Fuentes: =después de siete AÑOS (0.6) compartiendo con usted el Parlamento

now for a debate more or less (I)'m not going to quarrel with you ya por un debate más o menos no me voy a pelear con usted= 
$\begin{aligned} & \text { of course } \\ \text { Ms Álvarez: } & =\text { claro. }\end{aligned}$

In this extract the ECF 'todo' ('everything') is followed by an explicit challenge 'no todo no' ('not everything not'). But instead of softening it, Mr Fuentes goes on with his defiant speech and Ms Álvarez decides to finish with an ironic 'claro' ('of course') which is far from being an agreement.

Additionally, we can also observe a close relationship between repetition and floor management in this last extract. When Mr Fuentes says 'se lo permito todo' ('I permit you everything') Ms Álvarez repeats the ECF 'todo' ('everything') in order to take the floor. As Bamford (2000: 101) has already noted:

Interactants use repetition as a floor-seeking and floor-retaining tactic. In highly overlapped conversations, where there is competition for the floor, repetition is often used both to wrest the floor from another speaker and to keep it.

Tannen (1989) has also included in her list of functions of repetition in interaction 'getting or keeping the floor' (Tannen, 1989: 51). In this list she also includes uses such as: showing listenership, providing backchannel response, stalling, gearing up to answer or speak, humour and play, savouring and showing appreciation of a good line or a good joke, persuasion, linking one speaker's ideas to another's, ratifying another's contributions (including another's ratification), and including in an interaction a person who did not hear a previous utterance. In a footnote, Tannen (1989) acknowledges that there are also negative functions of repetitions and among these we can find: to challenge, question, mock, ridicule, and trivialize.

\section{Sequential organization in conversation}

In relation to the sequential organization of ECFs in Spanish, the following distribution was found:

Two different examples of ECFs were found in two concluding remarks of turns. From a rhetorical point of view, the conclusion of a speech plays a very important role. The speaker knows that the hearer will normally remember the very last words of his/her speech and not the whole talk and for this reason s/he should be as concise as possible but, at the same time, as informative as possible. So, ECFs are used to help the speaker express his/her stance in a succinct and revealing way. In the following example Mr Ortega concludes his turn saying that Andalusia does not develop properly because they are constantly quarrelling:

\section{Fourth recording: 4 March 2004:}

and here only we agree in quarrelling and that is what

Mr Ortega: (...) y aquí sólo nos ponemos de acuerdo en pelearnos y eso es lo que

Makes that Andalucía does not develop at a pace steady hace que Andalucía no se desarrolle a un ritmo adecuado.

Seven ECFs are related to the turn-taking system: some speakers are interrupted when they are uttering an ECF. This proves the stirring effect of ECFs: they are so emotion-charged that they make people react in favour of/against them. In the following extract Mr Caballos (PSOE party) is saying that Ms Martínez 
(PP party) is the worst valued leader of all the candidates and then he is interrupted by Mr Sanz (PP party). After that interruption Mr Caballos repeats what he said right before and goes on talking.

\section{First recording: 5 February 2004:}

that Teófila Martínez is the leader political worst

Mr Caballos: (...) que Teófila Martínez (0.7) es (0.3) la LÍDER política peor valued of the four that compete valorada (0.2) de los cuatro que se presen [tan]

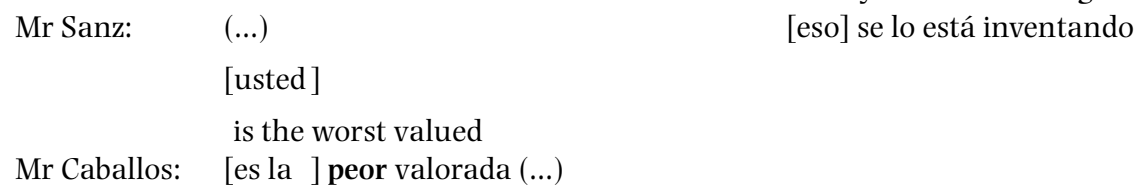

Five different examples of ECFs were found right before and/or after a big pause which is not in a transition-relevance-place. These pauses are longer than 0.5 seconds. Again, this is a rhetorical device used in order to highlight the ECF. In the following example Mr Ortega is explaining the reasons why North American businessmen did not invest in Algeciras port:

\section{Fourth recording: 4 March 2004:}

Mr Ortega: $\quad$ (...) cogieron un helicóptero (0.3) sobrevolaron el Puerto y se fueron
without investing for one single reason because they realised
sin invertir (0.7) por una sola razón (0.7) porque se dieron cuenta (...)

One ECF was found in a rhetorical question and another one in an answer to a rhetorical question. So we can say that ECFs are associated to rhetorical talk. The reason is crystal clear: a rhetorical question is answered by the same person who posed it or is just not intended to be answered at all so it will not be refuted. For this reason, the speaker can allow him/herself to be as extremist as s/he pleases. In the following extract, $\mathrm{Mr}$ Sanz (PP party) is explaining the reasons why Ms Martínez (PP party) is not the worst valued leader of all the candidates:

\section{First recording: 5 February 2004:}

Look I do not understand you Mr Caballos How can be the worst Mr Sanz: $\quad$ Mire yo no le entiendo Sr. Caballos (0.4) ¿Cómo puede ser la peor valued Teófila Martínez and is the mayoress most voted in Spain? valorada Teófila Martínez y es la alcaldesa más votada de España? you have tried (1.1) Ustedes han intentado (...)

Another ECF was uttered when a politician was summarizing what another politician had just said. In this case, the rhetorical benefit of this strategy is to intensify what someone else has just said. In this way, a speaker can exploit to his own advantage what another one has said because s/he will offer his/her 
own interpretation. Previous to the following extract Mr Sanz (PP party) had just said that Andalusia is not progressing. Mr Caballos (PSOE party, the political party of the regional government) answers in the following way:

\section{First recording: 5 February 2004:}

That is that here will be very bad everything done but Andalusia

Mr Caballos: $\quad$ O sea (0.3) que aquí estará muy mal todo hecho pero Andalucía (0.6)

is working

está (0.8) funcionando (...)

Finally, an ECF is deployed in a complaint. Mr Sanz is complaining because Mr Caballos is interrupting him constantly. In order to intensify this complaint Mr Sanz uses this ECF:

First recording: 5 February 2004:

Yes let's see if you respect me once because no no respect

Sr Sanz: $\quad$ Sí a ver si me me respeta alguna vez porque no:: no respeta absolutely nothing and the thing is

absolutamente nada y es que (...)

\section{ENGLISH PANEL INTERVIEWS}

The English corpus selected for analysis is made up of nine recordings of nine panel interviews broadcasted by the BBC. They all come from the well-known programme Newsnight. In this type of interview each interviewee does not have a pre-established time to talk and turn-to-turn discussion among interviewees is allowed. The interviewer is very active because s/he constantly asks questions to keep the panel alive and interesting.

The length of these recordings is 77 minutes and 58 seconds. There are three interviewees in four of them and only two in the rest. The interviewees range from politicians to professors and journalists. In fact, we can divide these recordings in three groups: 1) The political panels where all the participants are politicians; 2 ) the socio-political panels where interviewees are not only politicians but also people like professors, journalists, executives, writers, etc.; and 3) the social panels where there are no politicians and the issues dealt with are related to social topics. The details of each of these recordings are:

- First recording:

Name of the panel: 'Hutton Inquiry'

Type of panel: political

Date: 26 September 2003

Duration: 9 minutes and 6 seconds

Interviewees: Shadow Home Secretary Oliver Letwin MP (Conservative); Foreign Affairs Select Committee Gisela Stuart MP (Labour); Foreign Affairs Menzies Campbell MP (Liberal Democrats).

Interviewer (IR): Mark Urban

- Second recording:

Name of the panel: 'The Great Salt Scandal'

Type of panel: socio-political

Date: 18 June 2004 
Duration: 10 minutes and 20 seconds.

Interviewees: Professor Graham MacGregor (Consensus Action on Salt and Health); Deputy Director General Martin Paterson (Food and Drink Foundation); Public Health Minister Melanie Johnson MP (Labour).

Interviewer (IR): Kirsty Wark

- Third recording:

Name of the panel: 'Fourth State'

Type of panel: social

Date: 22 June 2004

Duration: 9 minutes and 25 seconds

Interviewees: John Lloyd (author); Melanie Phillips (Columnist, Daily Mail);

Richard Sambrook (Director, BBC News)

Interviewer (IR): Kirsty Wark

- Fourth recording:

Name of the panel: 'Legitimate Political Attack'

Type of panel: political

Date: 21 May 2004

Duration: 7 minutes and 47 seconds

Interviewees: Shadow Defence Secretary Nicholas Soames (Conservative); former Minister Peter Mandelson (Labour)

Interviewer (IR): Kirsty Wark

- Fifth recording:

Name of the panel: 'Open Letter to the PM'

Type of panel: political

Date: 27 April 2004

Duration: 8 minutes and 30 seconds.

Interviewees: Former British Ambassador to Libya Oliver Miles; Chairman of the Foreign Affairs Select Committee Donald Anderson (Labour).

Interviewer (IR): Jeremy Paxman

- Sixth recording:

Name of the panel: 'Interest Rates'

Type of panel: socio-political

Date: 7 May 2004

Duration: 5 minutes and 40 seconds

Interviewees: Chancellor of Exchequer 1993-7 Kenneth Clarke MP (Conservative); Chief Executive Will Hutton (The Work Foundation)

Interviewer (IR): Kirsty Wark

- Seventh recording:

Name of the panel: 'The Unconquerable World'

Type of panel: social

Date: 30 March 2004

Duration: 7 minutes and 4 seconds.

Interviewees: Professor Ruth Wedgwood; Jonathan Schell (author)

Interviewer (IR): Kirsty Wark

- Eighth recording:

Name of the panel: 'Tim Yeo on Tuition Fees' 
Type of panel: socio-political

Date: 22 January 2004

Duration: 14 minutes and 22 seconds

Interviewees: Shadow Education Secretary Tim Yeo MP (Conservative); Vicechancellor of University of Buckingham Dr Terence Kealey; Professor Nicholas Barr (London School of Economics)

Interviewer (IR): Jeremy Paxman

- Ninth recording:

Name of the panel: 'Kerry Speech'

Type of panel: social

Date: 2 August 2004

Duration: 5 minutes and 44 seconds

Interviewees: Journalist Susan Page (USA Today); Editor Peter Beinart (The New Republic)

Interviewer (IR): Kirsty Wark

Finally, we are also going to study the relationship between ECFs and a) the type of recording (i.e. political, social or socio-political), b) the interviewers (i.e. Wark, Urban and Paxman), and c) the interviewees (i.e. a politician or a journalist or an author, etc.). The analysis revealed the following results (see Tables 2-4):

TABLE 2. ECFs and types of recordings

\begin{tabular}{lccc}
\hline & Political & Socio-political & Social \\
\hline Time & 1.523 seconds & 1.822 seconds & 1.333 seconds \\
& $\left(253^{\prime \prime}\right)$ & $\left(30^{\prime} 22^{\prime \prime}\right)$ & $\left(22^{\prime} 13^{\prime \prime}\right)$ \\
ECFs & 43 & 21 & 17 \\
Rate & $2.8 \%$ & $1.2 \%$ & $1.3 \%$ \\
\hline
\end{tabular}

TABLE 3. ECFs and interviewers

\begin{tabular}{lcc}
\hline & K. Wark & M. Urban and J. Paxman \\
\hline Number of panels & 6 & 3 \\
Time & 2.760 seconds & 1.918 \\
& $\left(46^{\prime}\right)$ & $\left(31^{\prime} 58^{\prime \prime}\right)$ \\
ECFs & 13 & 2 \\
Rate & $0.5 \%$ & $0.1 \%$ \\
\hline
\end{tabular}

Table 4. ECFs and interviewees

\begin{tabular}{lcc}
\hline & Politician & Non-politician \\
\hline Number of interviewees & 10 & 12 \\
ECFs & 48 & 18 \\
Rate & $4.8 \%$ & $1.5 \%$ \\
\hline
\end{tabular}


Lexico-grammatical repertoire

The total number of ECFs found in this corpus is 81. After a having analysed all of them I arrived at the conclusion that they could be classified in five categories. The criteria used for this classification is twofold: syntactic and semantic. In this way, we find the following categories: totality, exclusiveness or zero, extreme adjectives or adverbs and superlatives, formulaic expressions, and softened or negated ECFs.

Totality These EFCs express the total number or amount of something or describe something which happens all the time. These are: seven 'always', one 'every', one 'full set of', 14 'all', four 'whole', three 'everybody', four 'entirely', one 'everything', one 'overwhelmingly', one 'totality', one 'full', one 'complete' and one 'completely'. Again, the most numerous of all ECFs is 'all'. Here is one example of each:

First recording: 26 September 2003:

Ms Stuart: I think that has been rather unfortunate over the last few weeks that there was always an assumption that the committee ehh divided on strict party political lines (0.5) ahh that has not been the case we have taken our duty ehh very seriously and have not seen it as a party political exercise (0.4) and we've already seen eh quite pointless information like ehh there was an assumption that a Labour members had a:: blue set blue sheets of questions from which we asked our:: witnesses these are the kind of sheets of questions that every select committee clerk prepares for every select committee for every member (0.4) and one of the things which I do hope that a:: Lord Hutton will take up (0.3) is offer a full set of documents of the committee including ehh notes and preparations a:: which will allows us for the first time to really see the complete picture on the basis of which we arrived at our decisions.

Exclusiveness or zero In this category we include examples of absolute negation or instances of ECFs which describe qualities limited to a particular person or group. We found the following formulations: two 'simply', two 'none', two 'anybody', five 'never', one 'anything', and one 'only':

Eighth recording: 22 January 2004:

Mr Yeo: when when I've laid out the details of the policy I'm confident that a IR: significant number will (0.2) [and I ]

$\uparrow$ [so the] answer is right now none?

\section{Ninth recording: 2 August 2004:}

Mr Beinart: I:: think most people have always imagined that it will be a vicious campaign I think the truth of the matter is given than Bush's ratings are below 50\%, I don't think they will get above 50\% he has to raise John Kerry's negatives it will be the only way he can win this race he has no choice but to go hard against John Kerry John Kerry will respond very strongly they remember the lessons of 1988 when Michael Dukakis didn't. 
Extreme adjectives or adverbs and superlatives This category is made up of adjectives which express the greatest degree of a particular quality and adverbs which denote the highest frequency of an event. In this group we found: three 'biggest', one 'best', four 'most', two 'worst', one 'highest', one 'oldest', one 'inevitable', one 'perfectly', three 'absolutely', and one 'extremely':

First recording: 26 September 2003:

IR

To assess the political impact of all this (0.4) are:: Oliver Letwin (0.2) for the Conservatives (0.4) Menzies Campbell for the Liberal Democrats and Gisela Stuart (0.5) for the Labour Party (0.4) Oliver Letwin if I can start with you $(0.4)$ what $><$ is $><$ the $><$ question $>$ you want answered most of all by this inquiry? (1.7)

Mr Letwin: well I suppose what we most needed to understand (0.5) is (0.8) a:: $<\underline{\text { how }}>$ that $(0.5)$ dossier came to be in the condition $(0.5)$ that it did come to be in (0.6) and what role the various actors (0.6) played in it $(0.8)$ that is a more important question about the trust worthiness of the information given to Parliament and the the electorate.

Formulaic expressions We found one example of a formulaic expression: 'across the board from the left to the right':

Third recording: 22 June 2004:

IR: $\quad$ Melanie what John Lloyd has also been talking about is that journalists have produced a culture of scorn $(0.4)$ presumably you would even say that was right across the board from the left to the right?

Softened or negated ECFS In this category we include ECFs which are modified in the sense that they are softened by a pre-modifier or negated: 'almost impossible', 'almost entirely', 'almost limitless', 'don't always' and 'didn't always' :

First recording: 26 September 2003:

Mr Campbell: well that is a question that is almost impossible to answer (0.5) a:: I think it's inevitable that there will be:: if you like accompanying commentary (0.4) a:: Gisela's hopes I think are:: vain (0.5) the precedent of the Scot inquiry is not all that long ago in our minds (0.4) throughout the course of that there was essentially a running commentary (0.3) as witnesses came and gave evidence and that evidence was (0.5) subject to very considerable scrutiny by press and (0.4) politicians alike (0.4) I think from the Government's point of view the next two or three months $(0.5)$ will be pretty difficult INDEED (0.4) so as far as the Government and the BBC are concerned let me say this by $(0.4)$ way of conclusion (0.3) and it's not because this is a $\underline{\mathrm{BBC}}$ programme (0.4) if it comes to a shoot out between the Government and the $\langle\mathrm{BBC}\rangle(0.3)$ as to which is to be regarded as more credible (0.4) then I think the Government may be in for something of a shock. 
Sixth recording: 7 May 2004:

Mr Clarke: I think so I never agree with conspiracy theories (0.3) and I think this one is wrong. I don't always agree with Mervyn King (0.4) I didn't always when he advised me when I did the job.

\section{Discourse processes}

Repetition is another discourse process we have found in the English corpus. This is an important phenomenon to take into account because as Wong (2000: 408) points out 'Indeed, repetition is a human, social activity, clearly part of our everyday conduct and behavior and not just a marker of a "disfluent" or "sloppy" speaker.'

Up to eight repetitions were analysed: 1) 'most - most', 2) 'every - every every', 3) 'anybody - anybody', 4) 'completely unnecessary - completely unnecessary', 5) 'entirely - entirely', 6) 'all these things - all these things - all these things', 7) 'never - never', and 8) 'don't always didn't always'. Most of them (i.e. the second, the third, the fifth, the seventh and the eighth) were produced by the same speaker and in the same turn; two of them were uttered by different speakers and in different turns (i.e. the first and the fourth); and only one was delivered by the same speaker but in different turns (i.e. the sixth).

\section{Second recording: 7 May 2004:}

IR: Why can't you make a a commitment (0.2) that no packaged sandwich no packaged sandwich (0.4) will have more than 2.5 grams of salt? (0.2) It is completely unnecessary for it to have more than that ADMIT the commitment. (0.4)

Mr Paterson: because that's not the case it is completely unnecessary first of all [people ( ) ]

IR: [because the] food is not good enough and you have to mask it?

The above example is interesting because an interviewee repeats an ECF which has been previously used by the interviewer. The interviewer's utterance is very aggressive and hostile and the interviewee decides to counter-attack using the same ECF. This is a new discursive use of ECFs. Far from the 'ECF-challengesoftener' sequence proposed by Edwards (2000), the challenge is substituted by an attack in the form of a repetition. According to Tannen $(1987,1989)$ and Couper-Kuhlen (1996) one reason why speakers use repetition is to express affiliation or support:

... speakers who are engaged in verbal interaction with one another employ adaptive strategies which entail 'matching' their speech behaviour in one way or another to that of their interlocutor. On the verbal level this matching may involve repetition of words, expressions or whole utterances. (Couper-Kuhlen, 1996: 366)

Clearly, this is not the case here. In this example repetition is used to attack the interlocutor. But as Johnstone et al. (1994: 7) explain 'Repetition is both collaborative, on the textual level of jointly creating cohesion, and conflictual, on the ideational level.' It is conflictual because they argue that 'One function of repetition is to preface or to express disagreement ... The closer the repetition is to 
identical, the closer it often is to direct disagreement' (Johnstone et al., 1994: 7). Bamford (2000: 119) has also noted that 'Another typical way of disagreeing with the previous speaker is to "echo" all or part of their immediately prior turn.'

In this extract, Mr Paterson uses the same ECF but applied to a different concept: the interviewer says that it is completely unnecessary that packaged sandwiches have more than 2.5 grams of salt and urges him to make a commitment and Mr Paterson answers that what it is completely unnecessary is to make a commitment. Nevertheless, it could also be argued that it is the interviewer himself who offers a softener version in the sense that he adds 'because the food is not good enough and you have to mask it'. The interviewer now provides a basis for adding the salt as in some sense necessary, albeit for an ignoble reason: 'you have to mask it'. This is, grammatically, a modal expression of deontic necessity ('have to' cf. 'must'), by which the interviewer promotes a modified notion of necessity, but restricted now to this rather ignoble motive of 'having to' mask the flavour of poor quality food.

\section{Sequential organization in conversation}

In relation to the sequential organization of ECFs in English, the following distribution was found:

Four ECFs were related to the topic organisation of turns: a speaker A begins his/her turn using the same ECF that a speaker B deployed when finishing his/her speech. In this way, ECFs are used as a device to give continuity. Additionally, as we all know most interviewees (mainly politicians) are normally accused of being deviant; using this strategy they show the audience that they are being direct. In the following extract the interviewer (Mr Urban) is asking Mr Letwin (Shadow Home Secretary) about the Hutton inquiry:

First recording: 26 September 2003:

Mr Urban: (...) What is the question you want answered most of all by this inquiry?

Mr Letwin: Well (0.6) I suppose (0.4) what we most needed to understand is (...)

Thirteen ECFs were used in prefatory (six) and concluding remarks (seven). The prefatory remarks were deployed by the interviewers with the purpose of providing a suitable background to the questions. So, we can say that one of the rhetorical uses of ECFs is to help the interviewer contextualize his/her question. In the following extract the interviewer Kirsty Wark is asking John Lloyd (journalist and author of a book about the relationship between the mass media and politics) about the role of journalists in the political arena in these times:

Third recording: 22 June 2004:

Ms Wark: John Lloyd, first of all, you assert that journalists of all opinions, including senior journalists at the BBC, publish and broadcast scorn for Parliament and claim that they should act as the true opposition to the Government of the day (0.5) What makes you say that?

Mr Lloyd: Columns by, for example, Jon Humphreys. 
Similarly, ECFs were also used when an interviewee is concluding his/her answer. The conclusion of a speech is the most important part of a piece of discourse because that is the message most easily remembered by the audience. So, we can affirm that ECFs play a very important rhetorical role. In the following example Ms Gisela Stuart (Labour MP, Foreign Affairs Select Committee) is claiming that the Hutton Inquiry should follow the appropriate processes; she concludes saying that:

First recording: 26 September 2003:

Ms Stuart: (...) then that is simply the best evidence that is available at the time.

ECFs are also highly related to the turn-taking system because three of them were found in interruptions. As it was previously said (in the Spanish corpus) ECFs are so emotion-charged that they make people react in favour of/against them. In the following example Peter Mandelson (Labour MP) is enumerating Iraqi people's desires. Then he is interrupted by Kirsty Wark:

Fouth recording: 21 May 2004:

Mr Mandelson: (...) They want to see international reconstruction, and a fresh UN council resolution. They want to see all [these]

Kirsty Wark: political [issue]

[But] surely the domestic
Mr Mandelson: $\quad[\mathrm{No}](0.4)$ hold on a moment (0.5) they want to see all these things in place (...)

ECFs were also used when the interviewer was providing a direct answer. So, ECFs help the speaker reinforce an answer which is definite and straightforward. Five instances were found, in the following one Mr Paterson (Deputy Director General, Food and Drink Foundation) answers in a very unequivocal way to a question posed by Kirsty Wark:

\section{Second recording: 18 June 2004:}

Ms Wark: What you are saying (0.4) then (0.3) is education is not our role? Mr Paterson: No (0.4) not at all (0.4) we have been calling for education (...)

Similarly, when a speaker wants to emphasize an agreement or a disagreement s/he may use an ECF. As a matter of fact, three instances were found. They help the speaker highlight his/her position towards something. In the following extract Kirsty Wark is asking Kenneth Clarke (Conservative Party MP, Chancellor of the Exchequer 1993-7) about interest rates:

Sixth recording: 7 May 2004:

Ms Wark: Let's deal with this naughty issue of the truth. Is the Bank of England telling the truth when they say they are moving for inflationary reasons?

Mr Clarke: I think so (0.4) I never agree with conspiracy theories (...)

Finally, four different examples of ECFs were found right before and/or after a big pause which is not in a transition-relevance-place. These pauses are longer than 0.5 seconds. They are used in order to isolate the ECF for rhetorical reasons. 
In the following transcription Peter Mandelson (Labour MP) is talking about the relationship between PM Blair and President Bush in concerning the Iraqi crisis:

Fourth recording: 21 May 2004:

Mr Mandelson: (...) That is much more important than any sort of grandstanding that Michael Howard advocates (0.4) trying to shun America or isolate the United States is absolutely (0.7) pointless.

\section{Discussion}

When we compare the number of ECFs found in the Spanish and in the English corpora (48 versus 81 ), we discover a considerable difference. English ECFs almost double Spanish ECFs. This difference could be due to three different factors: 1) cultural differences; 2) differences of style; and 3) the fact that one is more spontaneous than the other. In relation to cultural differences, it should be noted that Spitzbardt (1963) had already pointed out that American English is more hyperbole-prone than British English. So, it seems that culture could be an important factor to take into consideration. Nevertheless, we also have to take into account that whereas all Spanish recordings were pre-electoral political debates, English transcriptions were a mixture of social, socio-political and political recordings. Finally, it is necessary to mention that Spanish recordings were debates and that means that the turn-allocation system was very strict and the interviewer's role was that of a pure moderator who asked no questions and interviewees only spoke when it was their turn. In contrast, English recordings were much more lively in the sense that speakers could talk when they pleased and when the interviewer asked them questions.

If the second factor (i.e. differences of style) were relevant, that would imply that we should find many more ECFs in socio-political and social recordings. If we look at Tables 2 and 4, we will discover that the opposite happens: a) interviewers and interviewees deployed many more ECFs in political recordings ( 2.8 percent) than in socio-political (1.2 percent) or social recordings (1.3 percent); and b) politicians used more ECFs (4.8 percent) than any other type of interviewees (1.5 percent). So, it seems that politics favours ECFs. We all know that political language is a highly strategic type of speech where politicians are constantly using different linguistic tools to persuade their opponents. As has been previously mentioned, hyperbole is a well-known persuasive strategy commonly used when we want to distort the original meaning of something in order to gain advantage. Another common rhetorical strategy used when trying to persuade someone is repetition. One of the rules suggested by Roiz (1993) is the 'repetition of topics and ideas in an orchestral way' and Cockcroft and Cockcroft (1992: 131) explain that 'This [repetition] is probably the major resource of schematic rhetoric and the one with closest affinity to the spontaneous expression of emotion.' In the analysis of the corpora we found that a common discourse process used in Spanish and English was the repetition of ECFs. So, it would seem that ECFs are also closely connected to persuasion and exhortation. 
This strategic use of ECFs has also revealed two more special uses which vary from the sequence ECF-challenge-softener proposed by Edwards (2000). We have found two important deviations:

- ECF-challenge- $\phi$ softener

- ECF-attack (repeated ECF)

In general, these two types of sequence are face-threatening acts in the sense that they put their addressee's face in jeopardy. There is another fact which supports this hypothesis: 62.5 percent (i.e. 30/48) of the ECFs found in the Spanish corpus were used in a negative context, that is, to utter a negative quality or to attack.

Finally, it is also worth mentioning the role of the interviewers (see Table 3). The Spanish interviewer is a moderator and s/he never uses a single ECF. The British interviewers behave in quite different ways. Mr Urban and Mr Paxman only used three ECFs $(0.1 \%)$ and Ms Wark deployed six $(0.5 \%)$. According to Clayman $(1988,2002)$ interviewers should display neutrality in news interviews but he warns that "Maintaining neutralism becomes more complex within panel interviews where interviewers ask questions of different interviewees in succession' (Clayman, 2002: 1385). This explains two important things: 1) the reason why interviewers in general use so few ECFs; ${ }^{4}$ and 2) the reason why it is so difficult for Kirsty Wark to maintain neutrality. If ECFs have a persuasive function, then it is normal that interviewers do not use them but this becomes more difficult in panel interviews because interviewers get so involved in the discussion that they often take sides.

\section{NOTES}

1. It means sententious, trying to appear wise, clever and important.

2. This is an English adaptation, the original table is in Spanish.

3. Smith (1657).

4. 0 percent of their talk in the Spanish corpus; and only 0.1 percent and 0.5 percent in the English one.

\section{REFERENCES}

Bamford, J. (2000) You Can Say That Again: Repetition in Discourse. Bologna: Clueb. Billig, M. (1991) Ideology and Opinions: Studies in Rhetorical Psychology. London: Sage.

Clayman, S.E. (1988) 'Displaying Neutrality in Television News Interviews', Social Problems 35: 474-92.

Clayman, S.E. (2002) 'Disagreements and Third Parties: Dilemmas of Neutralism in Panel News Interviews', Journal of Pragmatics 43: 1385-401.

Cockcroft, R. and Cockcroft, S.M. (1992) Persuading People. An Introduction to Rhetoric. London: Macmillan Press.

Couper-Kuhlen, E. (1996) 'The Prosody of Repetition: On Quoting and Mimicry', in E. Couper-Kuhlen and M. Selting (eds) Prosody in Conversation, pp. 366-405. Cambridge: Cambridge University Press.

Edwards, D. (2000) 'Extreme Case Formulations: Softeners, Investment, and Doing Nonliteral', Research on Language and Social Interaction 23(4): 347-73. 
Edwards, D. (2004) 'Analyzing Discourse: The Discursive Psychology of MindWorld Relationships', in H. Van Den Berg, M. Wetherell and H. Houtkoop (eds) Analyzing Race Talk. Multidisciplinary Perspectives on the Research Interview. Cambridge: Cambridge University Press.

Edwards, D. and Potter, J. (1992) Discursive Psychology. London: Sage.

Edwards, D. and Potter, J. (2001) 'Discursive Psychology', in A. McHoul and M. Rapley (eds) How to Analyse Talk in Institutional Settings, pp. 12-24. London: Continuum.

Ehrlich, S. (1994) 'Repetition and Point of View in Represented Speech and Thought', in B. Johnstone (ed.) Repetition in Discourse. Interdisciplinary Perspectives, pp. 86-97. Norwood, NJ: Ablex.

Gibbs, R.W. Jr (1994) The Poetics of Mind. Cambridge: Cambridge University Press.

Grice, H.P. (1975) 'Logic and Conversation', in P. Cole and J.L. Morgan (eds) Syntax and Semantics. Vol. 3. Speech Acts, pp. 41-58. London: Academic Press.

Johnstone, B. et al. (1994) 'Repetition in Discourse: A Dialogue', in B. Johnstone (ed.) Repetition in Discourse. Interdisciplinary Perspectives, pp. 1-20. Norwood, NJ: Ablex.

McCarthy, M. and Carter, R. (2004) “"There's Millions of Them”: Hyperbole in Everyday Conversation', Journal of Pragmatics 36: 149-84. [AQ]

Norrick, N.R. (2004) 'Hyperbole, Extreme Case Formulation', Journal of Pragmatics 36: 1727-39.

Pomerantz, A. (1984) 'Agreeing and Disagreeing with Assessments: Some Features of Preferred/dispreferred Turn Shapes', in J.M. Atkinson and J. Heritage (eds) Structures of Social Action: Studies in Conversation Analysis, pp. 57-101. Cambridge: Cambridge University Press. [AQ]

Pomerantz, A. (1986) 'Extreme Case Formulations: A Way of Legitimizing Claims’, Human Studies 9: 219-29.

Roiz, M. (1993) Técnicas Modernas de la Persuasión. Madrid: Eudema.

Smith, J. (1657) Mysterie of Rhetorique Unvaild. London: E. Cotes.

Spitzbardt, H. (1963) 'Overstatement and Understatement in British and American English', Philologica Pragensia 6: 277-86.

Tannen, D. (1987) 'Repetition in Conversation: Towards a Poetic of Talk', Language 63(3): 574-605.

Tannen, D. (1989) Talking Voices. Repetition, Dialogue, and Imagery in Conversational Discourse. Cambridge: Cambridge University Press.

Wong, J. (2000) 'Repetition in Conversation: A Look at "First and Second Sayings'”, Research on Language and Social Interaction 33(4): 407-24.

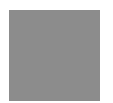

ISABEL ÍNI GO-MORA received her PhD from the University of Seville in 2001. Her interest is in discourse in general and discursive psychology in particular. She has written some works on political discourse and rhetoric. Some of her publications include: 'The Understanding of Utterances in Politics: A Case Study in Conversational Analysis' (Pragmatics Stakes: Understanding/Misunderstanding, 1998); 'La expresión del acuerdo y el desacuerdo en el discurso político: Un análisis social-cognitivo' (Philologia Hispalensis 16, 2002); 'On the Use of the Personal Pronoun We in Communities' (Journal of Language and Politics 3(1), 2004) and Comunicación y Discurso (Mergablum, 2003). ADDRESS: Facultad de Filologia Inglesa. C/Palos de la Frontera, s/n, 41004 Sevilla, Spain. [email: isabelin@us.es] 
